\title{
ADMISSIONS AS AN EXCEPTION TO THE HEARSAY RULE
}

\author{
EDMUND M. MORGaN \\ Professor of Law, Yale University, School of Law
}

Is an extra-judicial verbal admission by a party to an action receivable in evidence as an exception to the hearsay rule? That rule generally excludes extra-judicial statements when offered to prove the truth of the matter therein asserted. If admissions are received for any other purpose, or if they are received not as evidence, but as substitutes for proof, the query should be answered in the negative. Formal judicial admissions dispense with the necessity of evidence. They take the matter out of the domain of proof, so that neither court nor jury need make any finding with respect to them from the evidence. If a party in his pleading, or by stipulation, or by a formal declaration in open court admits the truth of any allegation, then so long as the pleading remains without amendment or so long as the admission stands unretracted, the allegation, for the purposes of the case, is taken as true by the court and jury, and no testimony by the admitter tending to show its untruth will ordinarily be received or considered. It has been suggested that extra-judicial admissions are to be received on the same basis "as a substitute for the ordinary and legal proof; in virtue of the direct consent and waiver of the party." "An admission," it has been said, "is a fact to be proved by evidence, not evidence to prove a fact." 2 These expressions appear to indicate that whenever a party is shown to have made an extra-judicial admission, he must be deemed to have waived proof by his opponent of the matter thus

\footnotetext{
${ }^{1}$ Greenleaf, Evidence (Ist ed., I842) sec. 169: "Such evidence seems, therefore, more properly admissible as a substitute for the ordinary and legal proof, either in virtue of the direct consent and waiver of the party, as in the case of explicit and solemn admissions; or on grounds of public policy and convenience, as in the case of those implied from assumed character, acquiescence or conduct." The learned author does not amplify his views, nor does he, in dealing with specific cases of admissions, explain in what way, if at all, the application of this theory would produce results differing from those produced by regarding admissions as exceptions to the hearsay rule. None of the editors of the later editions of the treatise make any comment upon this section, except Dean Wigmore, and he rejects its theory in favor of the theory explained infra, which regards extra-judicial admissions as merely impeaching evidence. Greenleaf, Evidence (I6th ed. I899) sec. 169. Mr. Pitt Taylor incorporated the quoted statement verbatim in the first paragraph of the fourteenth chapter of his work on Evidence, without comment or explanation.
}

'Wharton, Evidence (1877) sec. 1075; Hammersley, J. in State v. Willis (I894) 7I Conn. 293, 308, 4I Atl. 820, 823. 
admitted. It is possible that they may be taken to mean merely that there may be an extra-judicial waiver of the privilege of requiring the opponent to produce proof of a particular point in issue and that an admission is evidence of such waiver. ${ }^{3}$ In either event, when such an admission is offered, it may not properly be received upon the main issue, ${ }^{4}$ and in this sense, may properly be said not to be evidence. Upon the subsidiary issue, it is no more hearsay than is testimony of the words used by the contracting parties upon an issue as to the terms of an oral contract. Under such a doctrine, if the issue as to admission or waiver results in a finding of admission or waiver, then the matter involved is withdrawn from the realm of controversy; and no evidence upon that particular point is to be received or considered; if the finding is no admission or no waiver, then the matter covered in the alleged admission is still in issue, but the alleged admission may not be considered in arriving at a solution of the issue.

The objection to the foregoing theories is that they find almost no support in the judicial decisions. Extra-judicial admissions are not treated like judicial admissions, as substitutes for proof. No matter how clear may be the proof that the admission was made, it is not conclusive upon the admitter. ${ }^{5}$ Nor is the issue of waiver of proof considered separately and the admission confined in its operation to this issue. The admission goes to the jury with other evidence, and upon all the evidence the jury finds the facts as to the main issue. ${ }^{6}$

Two theories have been advanced which would recognize admissions as receivable as evidence in the case and yet keep them from running counter to the hearsay rule. The first, rather feebly put forth, is that the admission might be received, not as testimonial, but as circumstantial evidence. ${ }^{7}$ That is to say, the admission is to be received, not as

\footnotetext{
${ }^{3}$ If the former interpretation is accepted, the extra-judicial admission would seem to to be more potent than the judicial admission, for the latter, when improvidently made, may usually be amended or withdrawn. An extra-judicial verbal admission includes any statement made by a party inconsistent with the position taken by him in the action. It is perfectly clear upon the authorities that extra-judicial admissions are not conclusive upon the admitter, as was necessarily known to both the learned commentators above mentioned. It seems only reasonable, then, to conclude that when they spoke of admissions as a substitute for proof, they must have been using the term, "admission," to express the concept of waiver of proof, and not as designating merely the extra-judicial statement of the admitter.

"Hammersiey J. in State v. Willis, supra note 2. It must be remembered that this statement by the learned justice was pure dictum. The question before the court was the admissibility of a confession, which had been objected to because involuntary. The term "admission" is applied throughout the opinion to the confession.

${ }^{\circ}$ Heane v. Rogers ( 1829, K. B.) 9 B. \& C. 577 ; see 2 Wharton, op. cit., sec. ro77 and cases cited.

- Cases cited infra note 9. Greenleaf, Evidence (I6th ed., 1899) sec. I69.

'See (1920) 34 Harv. L. Rev. 205; I Wigmore, Evidence (I904) sec. 267.
} 
direct evidence of the facts therein asserted, but as circumstantial evidence indicating a belief of the admitter that the facts are inconsistent with the position he is now taking in the case. In other words, the fact of the utterance of the admission furnishes a basis for an inference as to the state of mind of the admitter; this state of mind in turn furnishes the ground for an inference to the facts which produced the state of mind. By this process of double inference, the same conclusion is reached as if the admission had been considered testimonially. It is submitted that such a doctrine is altogether too tenuous for practical application. Imagine attempting to expound it to the average jury!

The other theory is that admissions, properly understood, are offered and received solely to contradict the position taken by the admitter in the action, that their only purpose is to perform the function against a party which prior contradictory statements of a witness perform against the witness. They are received, not to prove the truth of the matter asserted, but to impeach. Their effect is purely destructive. ${ }^{8}$ But certainly this contention is contrary to the overwhelming weight of authority. Not only have the courts sharply distinguished between prior contradictory statements of mere witnesses and the admissions of parties, but they have also relied upon admissions as affirmative substantive evidence to sustain a verdict or finding of the truth of the matter admitted, and they have directly and emphatically disapproved instructions to juries to the effect that admissions were to be considered only as impeaching evidence. ${ }^{9}$

\footnotetext{
${ }^{8} 2$ Wigmore, op. cit., sec. I048; Greenleaf, Evidence (I6 ed., I899) sec. I69; (I920) 34 HaRv. L. REv. 205.

'Hall v. The Bark Emily Banning (1867) 33 Calif. 522. The opinion was rendered sustaining an order granting a new trial upon plaintiff's motion. After showing that plaintiff had not been directly impeached in her character as a witness, and that the only conflict in the evidence upon the question of damages was made by plaintiff's extra-judicial admissions, the court said: "The rule is settled beyond all controversy that the admissions or declarations of a party to a suit are admissible against the party making them. When given in evidence, they tend, as does other competent evidence, to prove the fact in issue to which they relate. We do not understand that the result of the permission given by statute to the parties to an action to testify in their own behalf has blended in one the different characters of party and witness, nor obliterated the distinction between admissions of parties against interest and statements out of court contradictory to their testimony at the trial." (This language was not strictly necessary to the decision.)

Estate of Ricks (I9II) I60 Calif. 467, 485, II7 Pac. 539, 546. Appellant had failed to deny a.statement made to a witness in his presence by his mother to the effect that he would take no further share of certain property. He requested the court to charge that his declarations or admissions could be considered only for the purpose of showing the feelings and relations existing between the parties. The court, in sustaining the trial court's refusal so to instruct, said: "The admissions and declarations against interest of the sole beneficiary are admissible to establish any fact in issue upon the validity of a will which they have a tendency to establish, and are not subject to the limitation appellant claims for them."
} 
The fact, then, is that admissions are not received as substitutes for evidence, nor as evidence merely of a waiver of proof, nor as circumstantial evidence from which by a double inference a conclusion of the truth of the matter admitted may be deduced, nor solely as impeaching or destructive evidence; they are received as evidence of the truth of the matter asserted in them. Prima facie they fall squarely within the prohibition of the rule against hearsay. Are they within any recognized exception?

Courts and text-writers frequently speak of extra-judicial admis-

O'Neil v. Redfield (1913) 158 Iowa 246,139 N. W. 555 . In an action for personal injuries due to an automobile collision, plaintiff offered in evidence a letter written by defendant. In holding that the trial court erred in rejecting it, the court said: "The writer of the letter being a party to the action, its admissibility did not depend upon whether it did or did not tend to impeach his credibility as a witness. It was admissible as his own statement of the facts, in language which is fairly open to the construction that he understood or conceded that the young lad had been injured by his automobile." Eight years before the same court had stated that an admission was receivable as substantive evidence against the admitter and not merely as discrediting testimony. Castrer v. C. B. \& $Q$. $R y$. (1905) I26 Iowa, 58r, 585, 102 N. W. 499, 50I.

Bartlett v. Wilbur (1879) $53 \mathrm{Md}$. 485, 497. After holding that an affidavit admitted by the trial court was inadmissible, the court said: "If admissible, however, at all, we agree with the appellants that the court erred in ruling that it could be offered only for the purpose of contradicting the testimony of the plaintiff. There is a wide difference between the declarations of an ordinary witness, a stranger to the suit, and the declarations of a party to the record. The former are admissible only for the purpose of impeaching or contradicting the witness, but the latter, being the admissions of the party to the suit, may be offered to prove the truth of the matters thus admitted."

McManus v. Nichols-Chisholm Lumber Co. (I908) I05 Minn. 144, I47, II7 N. W. 223, 224. The trial court had charged the jury in substance that prior statements of the plaintiff admitting contributory negligence (which in Minnesota is an affirmative defense) were to be considered only as discrediting testimony. In reversing, the court said: "But in the case of a party such admissions and statements may be received in evidence, without laying any foundation therefor, as evidence tending to establish the fact to which they relate. All admissions by a party, made outside the record, if relevant to the issue, are admissible in evidence, and such evidence has a two-fold effect. It tends, as does other competent evidence, to prove the fact in issue to which the admissions relate, and where they contradict the testimony of the party, the evidence tends to discredit him; or, in other words, such evidence is admissible to prove the fact admitted and to discredit the party."

Peterson v. Silver Peak (Igr4) 37 Nev. II7, I30, I40 Pac. 519, 524. In holding that the trial court erred in excluding certain extra-judicial admissions of plaintiff, the court said: "Any voluntary statement that respondent might have made subsequent to the accident as to the cause of the accident, or as to the agencies that brought about the accident, if such were made, might be produced by and from the party or parties to whom such utterances were made, on behalf of the contention of the appellant that the accident was not brought about by its negligence."

People v. Casica (I920) I9I App. Div. 376, I8I N. Y. Supp. 855. The court held that an admission by silence constituted supporting evidence to the unsworn testimony of an eleven year old boy. The statute required supporting evidence to sustain a conviction. 
sions as declarations against interest, ${ }^{10}$ and it has sometimes been assumed that if they are to be received at all as exceptions to the rule against hearsay, they must be brought within the exception of declarations against interest. With this assumption as a starting point, it has been pointed out that they lack the essentials of this exception. They are admitted regardless of whether they were, when made, against the pecuniary or proprietary interest of the admitter, and there is no requirement that the admitter be unavailable. It is next noted that the courts do not insist upon, if they even mention, either of these requisites. And the conclusion is deduced that admissions cannot be regarded as exceptions to the hearsay rule and their admissiblity must be explained upon other grounds. ${ }^{11}$ The difficulty with this line of reasoning is that it is founded upon a false assumption. Certain it is

Retter v. Olean Street Railway (1910) 140 App. Div. 667, 125 N. Y. Supp. 674 Held, that the trial court erred in limiting the effect of admissions to impeachment. It should have treated them as substantive evidence upon the issue.

State $v$. Jonas (1907) 48 Wash. 133, 92 Pac. 899. An admission of defendant that he had taken improper liberties with prosecutrix was held sufficient corroborative evidence.

Warder v. Fisher (1880) 48 Wis. 338,4 N. W. 470 . The court by way of dictum said: "The unsworn statements of a mere witness in the case, given in evidence to impeach his credibilty, are not received as evidence to prove either side of the issue in the case, but to cast doubt and suspicion upon the truthfulness of the contradictory statements made by the witness under oath; but when the witness who has made the contradictory statements out of court is also a party to the action, such unsworn statements are received, not only for the purpose of attacking the credibility of the sworn statements of the party, but for the purpose of establishing the truth of the unsworn contradictory statements themselves."

McKewen v. Cotching (1857) 27 L. J. Exch. 41. In an action for the conversion of a bill of exchange, the only evidence tending to show that it had ever been in the possession or control of defendant was his extra-judicial statement in response to a demand to deliver it up that he could not do so because it had been burned. On a rule for a new trial on the ground that there was no evidence to sustain a verdict for plaintiff, the court held this evidence sufficient.

I3 Halsbury, Laws of England, 456: "In civil cases, statements made out of court by a party to the proceedings are evidence of the truth of the facts asserted against but not in favor of such party."

${ }^{10}$ See e. g. I Phillipps, Evidence (14 Am. ed.) 402. "The principle on which they are received is founded chiefly on the reasonable presumption in favor of the truth of a statement, when it is against the interest of the person who makes it." It is curious that Wharton, who adopted the theory of Greenleaf that extrajudicial admissions are substitutes for proof, should say: "It is admissible in evidence, as, prima facie, a levamen probationis, but the only ground for its admission is the presumption that a declaration made by me against my interest is true." 2 Wharton, $0 p$. cit., sec. 1078 .

II Wigmore, op. cit., sec. ro49. It is submitted that the cases cited in note 9 supra demonstrate that the courts have not been misled as to the real nature of admissions, and when they use the expression, "declarations against interest," they are fully aware that the exception to the hearsay rule admitting declarations of unavailable declarants against their then pecuniary or proprietary interest is not broad enough to include many admissions. 
that extra-judicial admissions are received in evidence. Equally certain is it that they are received for the purpose of proving the truth of the matter admitted. It is likewise certain that they do not fall within that exception to the rule against hearsay which admits declarations against interest. These are the facts, and from them the conclusion is inevitable that they are received as an exception to the rule against hearsay, and not that they are received on any theory that they are not hearsay.

Is there a justification in principle for such an exception? The substantial reasons usually advanced for the exclusion of hearsay are, that the declarant whose statements are reported in court by the witness is in reality offering the testimony, and that this declarant is not under oath, does not confront the party against whom he is testifying, and is not subject to cross-examination. The danger that the witness may inaccurately report the declarations or may fraudulently modify or fabricate them is sometimes put forward as a supporting reason. That this danger is not and cannot be regarded as controlling is sufficiently shown by the fact that it would preclude all exceptions to the hearsay rule. Morover, it exists to a marked degree in many cases where the hearsay rule is not involved. For example, there is almost as great risk of such inaccuracy and dishonesty where the terms of an oral contract or the words of an alleged slander must be proved, and where the terms of a lost writing are in issue. And in such cases there can be no question of the admissibility of such testimony. Consequently, in those classes of cases where exceptions to the rule against hearsay have been established, the courts have appeared to require only some guaranty of truth in a degree serving the purpose of the oath and cross-examination, and some measure of necessity for resorting to the hearsay. This measure of necessity is found to vary from absolute necessity due to the impossibility of securing the attendance of the declarant in court, to the mere desirability of using the hearsay statement simply because it seems improbable that the declarant, though available, will furnish testimony in court of equal or greater reliability. ${ }^{12}$ It is to be further observed that in formulating these requirements, the courts have for their object chiefly the protection of the party against whom the evidence it to be used, rather than the establishment of a rule which automatically eliminates the possibility of false testimony. ${ }^{13}$

\footnotetext{
${ }^{12}$ On this question generally, see 2 Wigmore, op. cit., secs. 1362-1365.

${ }^{23}$ This is true as to other rules of evidence as well as hearsay. It is made clear by the facts, that the insistence of the courts in the exception for former testimony is upon opportunity for cross-examination rather than upon actual cross-examination; that while the court may, it rarely does, interfere sua sponte to prevent the introduction of incompetent evidence; that the reception of incompetent evidence is never ground for reversal unless objection to it was seasonably made; and that incompetent but relevant evidence, received without objection, is to be considered in determining the sufficiency of admitted evidence to sustain a finding or verdict.
} 
Applying these considerations to the policy of receiving extrajudicial admissions in evidence, it is too obvious for comment that the party whose declarations are offered against him is in no position to object on the score of lack of confrontation or of lack of opportunity for cross-examination. It seems quite as clear that he ought not to be heard to complain that he was not under oath. All the substantial reasons for excluding hearsay are therefore wanting. The subordinate reason based upon the possible inaccuracy or dishonesty of the witness is of much less force here than in the cases where he is testifying to statements of unavailable declarants. $\mathrm{He}$ is confronting the very person whose statements he is reporting, he is subject to cross-examination by counsel who has at his elbow the person who knows all the facts and circumstances of the alleged statements and who is therefore in the best possible position to conduct a searching inquiry, and, finally, the declarant may himself go upon the stand and deny, qualify or explain the alleged admissions.

Under these circumstances should the availability of the declarant operate to exclude his admission? Two considerations compel a negative answer. First, as has been observed, unavailability of the declarant is not a universal prerequisite to the admissibility of hearsay. A declaration as to a presently existing mental or subjective bodily condition, or a sportaneous exclamation ${ }^{14}$ is usually admissible, even though the declarant is present in court and the declaration or exclamation is offered in his behalf. Ordinarily there is quite as little likelihood of securing from the declarant in court testimony as trustworthy and free from bias as his extra-judicial admissions, as is the case with the declarations and exclamations just mentioned. Second, the admission is always offered against the declarant, and he cannot object to its being received as prima facie trustworthy, particularly when he is given every opportunity to qualify and explain it. To use the language of Baron Parke in Slatterie v. Pooley: "What a party himself admits to be true may reasonably be presumed to be so."15

It is, therefore, submitted that upon both principle and authority, extra-judicial verbal admissions by a party to an action are receivable in evidence under an exception to the rule against hearsay.

\footnotetext{
${ }^{14}$ There is, of course, a conflict of authority as to the admissibility of spontaneous exclamations which are not contemporaneous with the act to which they relate. See 3 Wigmore, op. cit., secs. 1745-1757. Contra, McCarrick v. Kealy, (1898) 70 Conn. 642, 40 Atl. 603.

${ }^{15}$ (I840, Exch.) 6 M. \& W. 664. See 2 Chamberlayne, Evidence (IgII) sec. 1292: "The competency of an admission is not so much an exception to the rule excluding hearsay as based upon a quasi-estoppel which controls the right of a party to disclaim responsibility for any of his statements." The so called "quasiestoppel" may furnish one of the reasons for making an exception to the hearsay rule, but it cannot prevent its being an exception.
} 